\title{
QUESTION WORDS IN THE INTERROGATIVE CONSTRUCTION IN JAVANESE: IN X-BAR THEORY
}

\author{
Mayasari, Mulyadi \\ Universitas Sumatera Utara, Medan, Indonesia \\ E-mail: mayasarispdmsi@gmail.com
}

Received: 15 January 2020

Accepted: 22 May 2020

\begin{abstract}
This study examines the syntactic behavior of question words (tembung pitakon) in the interrogative construction in Javanese. This study aimed to analyze the question words of all interrogative types in the language. Therefore, the research data cover question words known as tembung pitakon in Javanese which are derived from the relevant literature. The theoretical framework used in this study is the X-bar theory proposed by Haegeman (1992). The data analysis techniques used in this research were distributed methods which use the language element determination tool itself. The results show that the Javanese partial sentence has a grammatical and complementary grammatical function, while the total question sentence has a complement function. Javanese question words can be constructed by specifier, complements, and adverbials. The Javanese question sentence formed by specifier functions as an internal structure occupied by the NP and joined by I' to form an IP. Furthermore, the question words formed by complement functions as an internal structure occupied by PP or NP and joined by $\mathrm{V}$ to form the first V'. Finally, the question words formed by adverbial functions as an internal structure that can be occupied by PP or NP to join the first V' then form the second V'.
\end{abstract}

Keywords: interrogative, question word, X-bar theory, specifier, complement, adverbial.

\section{Introduction}

Aarts and Aarts (1982: 94-95) sentences into four types, namely, declarative sentence, interrogative sentence, imperative sentence, and exclamation sentence. Declarative sentence is a sentence which always has a subject which precedes the verb such as Paris is the capital city of France. Interrogative sentence is a sentence that contains a subject and can be formed with an auxiliary verb preceding the subject or with question words, as Are you all right? or Who wrote this letter?. Imperative sentence is constructed by a bare infinitive verb as Get out! and exclamation sentences are closed with an exclamation mark as What a building!

Interrogative sentence is used in communication involving a second person in a dialogue in the form of question and answer. The question sentence is used with the aim of getting a reaction in the form of an answer from a question or reinforcing something that the questioner already knows. What is called a question sentence is a sentence that functions to ask something (Alwi, 2003: 358; Ramlan, 2005: 28). When someone just meets another person also uses the question sentence to ask about their identity. Thus, question sentence is widely used in every day conversations. 
Research on the structure of the question sentence has been conducted by many researchers such as Hafrianto \& Mulyadi (2018) who discusses the structure of the sentence in Tamiang dialect using the X-bar theory. The results of this study explain that the types of total question sentences in Malay language of the Tamiang dialect use the answer Yes or No, while the partial question sentence requires an answer with an explanation.

Caesar (2016) analyzes various means of marking interrogatives in Dangme dialect covering polar, alternative, affirmative and negative content questions. Dangme dialect belongs to the Kwa group of languages from the Niger-Congo family of languages. It is spoken in parts of the Greater Accra and Eastern Regions of Ghana. A number of works on interrogative structures of Dangme dialect have been done so far because it is considered to be a vital feature of African languages. This paper examines various kinds of interrogative structures in Dangme dialect. The paper also examines negative interrogative sentences. The grammatical feature in the negative question constructions implies that it belongs to interrogative content questions.

Another research on X-bar theory was conducted by Mulyadi (2010) about Indonesian prepositional phrases. This study provides an internal structure of the prepositional phrases in Indonesian that are formed by complement, information and specifiers. Thus, it can be seen that the research of the structure of question sentences using the X-bar theory in Javanese is rarely found, whereas in other languages, a number of research have been conducted using X-bar theory.

Javanese has question words which make up question sentences. Many researchers review question words in various languages more deeply. In this study, the researchers used the X-bar theory to analyze the structure of question words in Javanese. The X-bar theory is an advanced theory of Generative Transformation Grammar which aims to divide the grammatical elements systematically in one complete sentence.

The purpose of this study is to analyze question words in the interrogative constructions in Javanese in the question words (tembung pitakon)in Javanese, they are apa (menapa)"what"; sapa (sinten) "who"; ing ngendi (wonten pundi) "where"; kepriye (kepripun, kadospundi) "how"; geneya (yagene, kena apa, kenging menapa) "why"; endi, pundi, ingkang pundi; ing ngendi "where"; menyang endi, dhateng pundi "to where"; saka ngendi, saking pundi "from where"; saka apa, saking menapa "from what"; saka sapa, saking sinten "from whom"; nganggo apa, ngangge menapa, ngagem menapa "with whom"; karo sapa, kaliyan sinten, kanggo sapa, kangge sinten, kagem sinten "with whom"; pira, pinten "how much"; kapan, dhek kapan, kala menapa, besuk kapan, benjang menapa "when" used in the Javanese question words as a dominant form of interrogative construction and its formation. To find out the form of interrogative construction in Javanese this study analyzes data by linking the use of X-bar theory.

Thus, this study discusses question words in the interrogative constructions of the Javanese language. Then, it suggests that this is a syntactic study as it involves the discussions of interrogative sentences. This is because syntax is the study of the rules of sentence formation from the combination of words in a language (Crystal in Putrayasa, 2017). The combination of words will form phrases and clauses, then clauses in a more perfect form will form sentences.

In Data 1, the interrogative sentence sentence makes use of a question word opo 'what'.

Data 1: Opo omonge wong mengko?

What say people later 
'What people will say later?'

DS

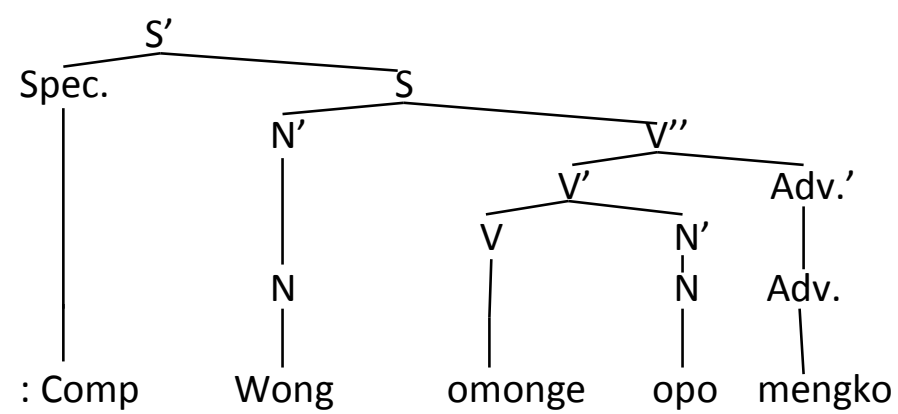

Verb Preposing:Comp omonge wong opo mengko

Wh-movem. : Comp opo omonge wong mengko

SS

: Opo omonge wong mengko?

'What people will say later?'

Data 2 : Sopo sing teko kae?

who (def. marker) came that(demonstr)

'Who came?'

DS

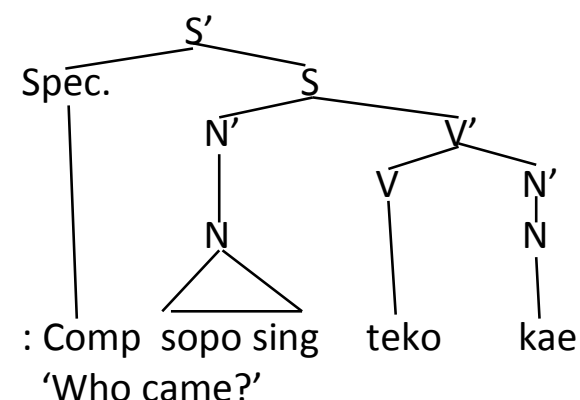

Data 3 : Sopo jenengmu?

Who name+your

'What is your name?

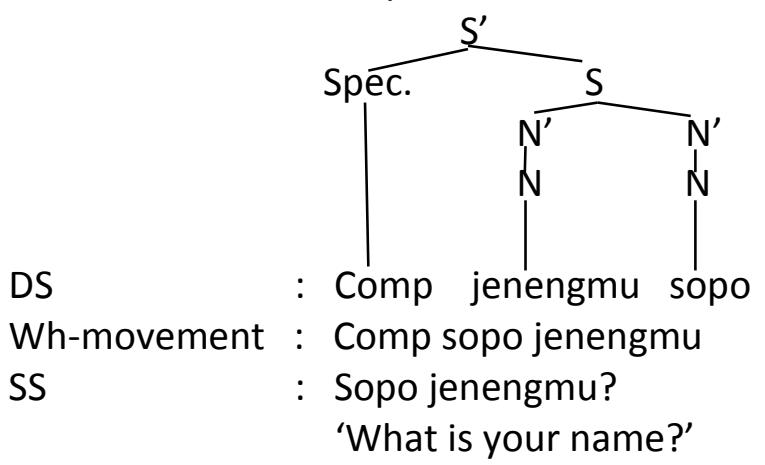

Thus, this study aims to analyze the structure of Wh-words in question sentences in Javanese using $\mathrm{X}$-bar theory covering the grammatical functions found in these types of question words, as well as lexical categories which include complement, adverb, and specifier. 


\section{Literature Review}

Interrogative sentences are used to elicit information that may or may not be known to the questioner to either seek for information or for clarification of what has already been uttered. Konig and Siemund (2007: 291) assert that interrogative sentences are conventionally associated with the speech act of requesting information. According to Dixon (2012), an utterance may be interrogative in structure but may function pragmatically as a command with or without non-verbal cues such as a smile.

Research on the structure of the question sentence has been conducted by a number of experts. Fitriyani (2018) conducted a study on question sentences in Minangkabau language. The result showed that a partial question sentence has two grammatical functions, namely the specifier and complement. The interrogative word iyonyo 'is it right?' in the total interrogative sentence functions as a complement.

This study uses the X-bar theory. In X-bar theory all phrases are dominated by one lexical nucleus. The core is the final node that dominates the word. The lexical core of the projection is a blank projection (Haegeman, 1992: 95). The syntactic categories of phrase constituents such as NP, PP, AP, VP, and AdvP are lexically determined. For example, the core of NP is a noun, the core of PP is a preposition, and so on. So, the core of PP nang ladang in the padi field' is nang 'in'. The nucleus is also located one level lower than the constituents that form the core. In the X-bar hierarchy, P as the core of PP lies one level lower than the phrase (Mulyadi, 2008: 23).

Next, the X-bar theory is represented in the tree diagram as below:

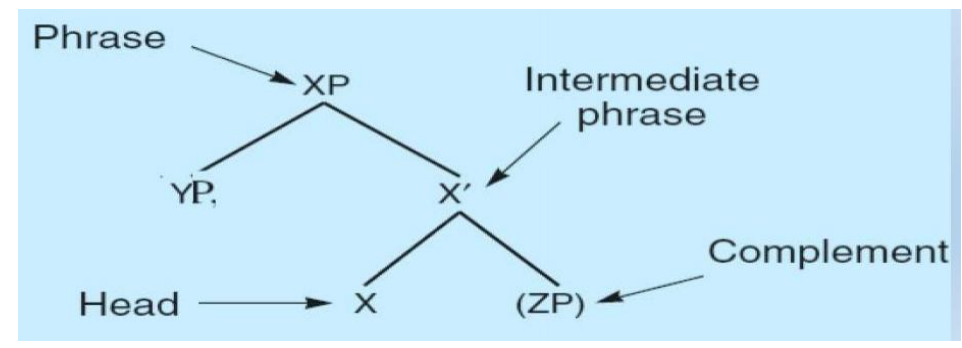

(Haegeman, 1992: 95)

The $\mathrm{X}$ symbol in the diagram above is a substitute for a lexical category such as nouns, verbs, prepositions, or adjectives and the dots on the left and right are filled with three grammatical functions, namely complement, specifier, and adjunct. The format for phrase structure is seen in the following rules.
a. $X^{\prime \prime} Y P ; X^{\prime}$
b. $X^{\prime} X^{\prime} ; Z P$
c. $X^{\prime} X ; W P$

Explanation:

YP : Specifier

ZP : Adjunct

WP : Complement

Complement combined with $\mathrm{X}$ forms $\mathrm{X}$-bar $\left(\mathrm{X}^{\prime}\right)$ projection; an adjunct combined with $X$-bar $\left(X^{\prime}\right)$ forms a higher $X$-bar $\left(X^{\prime}\right)$ projection, and a higher specifier that combines with $X$-bar $\left(X^{\prime}\right)$ forms the maximum projection of the phrase $X\left(X^{\prime \prime}\right)$. The bar category is the $X$ projection and the phrase with the highest bar is the maximum projection from the $X$ category. In this case, the specifier is not only located at the beginning, but also at the end. 


\section{Research Methods}

This study applies descriptive methods that are closely related to qualitative methods and the characteristics of natural settings. Descriptive method is used with the consideration that this study focuses on the characteristics and nature of language naturally (natural language) as well as the reality of language as it is empirically still alive in the use of the language concerned.

The data in this study are question words (Tembung pitakon) in Javanese. This study aims to analyze the question words of each interrogative type. The research data in the form of question words in Javanese known as tembung pitakon in the language.

The data analysis model used in this study is the model of distribution. The distribution method uses the determinant of the language element itself such as words (prepositions, denials, adverbial), syntactic functions (subjects, objects, predicates), clauses, syllables, and so on (Sudaryanto, 2015: 15). In this study there are 18 data in the form of question words that mark each type of interrogative sentences and have a variety of patterns, including question words which can correlate with various syntactic categories such as words, phrases, or clauses.

From these 13 data, there are 3 of them which are analyzed by the distributional method and the substitution technique and used to identify the lexical and grammatical functions of question words.

Data 4. Kepriye carane kowe nggawe tahu?
Adv.P NP VP
How 'How do you make tofu?'

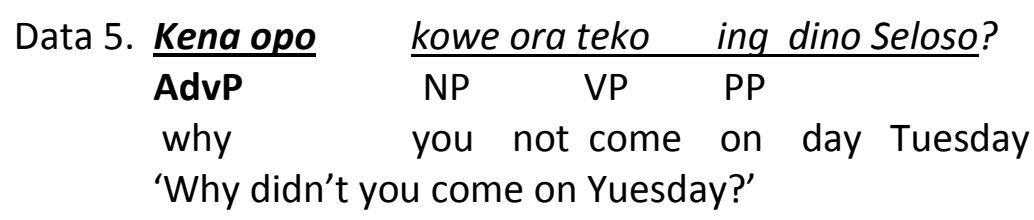

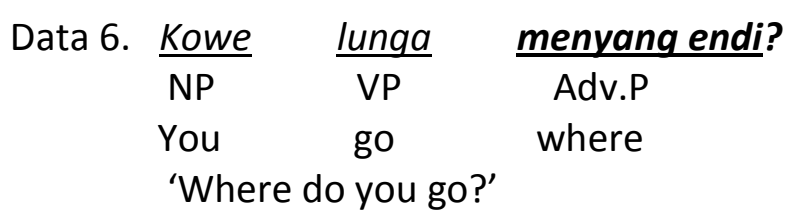

The NP kowe 'you' in data (3) and (4) is placed in the middle of the question sentence, while in data (5) it is placed at the beginning of the sentence. At this stage it can be seen that the question word kowe has a lexical function as a noun, so the question word has a position dominated by the specifier.

To analyze and identify data, X-bar theory is used. X-bar theory can explain whether in a phrase or clause can provide a function of each category of words. The X-bar theory uses tree diagrams that can see the structure in question sentences in Javanese.

\section{Results and Discussion}

\subsection{Results}

The Javanese question sentence can be formed by the specifier as an internal structure occupied by the NP and joined by I' to form an IP. Furthermore, the question word in Javanese 
can be formed by complement as an internal structure occupied by PP or NP and joined by $\mathrm{V}$ to form the first $V^{\prime}$. Furthermore, it can be formed by adverbial as an internal structure that can be occupied by PP or NP to join the first V' then form the second $\mathrm{V}^{\prime}$.

The following are a few examples from the data.

(1) Dheweke asli soko ngendi?

He really from where

'Where does he really come from?'

(2) Jajan iki digawe soko opo?

Snack this made (passive) from what

What is this snack made from?)

(3) Piro cacahe dhuwit sing kok duweni?

How much variant money that you have

'How much money do you have?'

The Javanese question sentence consists of a total question sentence and a partial question sentence. The structure of a partial question sentence that begins with a question word is not always an interrogative sentence because it may function as a noun clause as the object of a verb in the principal clause as in the following sentences.

(4) Kapan kowe mulih seko Jakarta, aku ora weroh.

When you come back from Jakarta, I not know

'I don't know when you are coming back from Jakarta.'

In (4) the main clause Aku ora weroh 'I don't know' is preceded by the complement cluse kapan kowe mulih seko Jakarta 'when you come back from Jakarta' in which the complement clause begins with a question word kapan 'when' but it is not an interrogative sentence as illustrated in the following phrase markers.

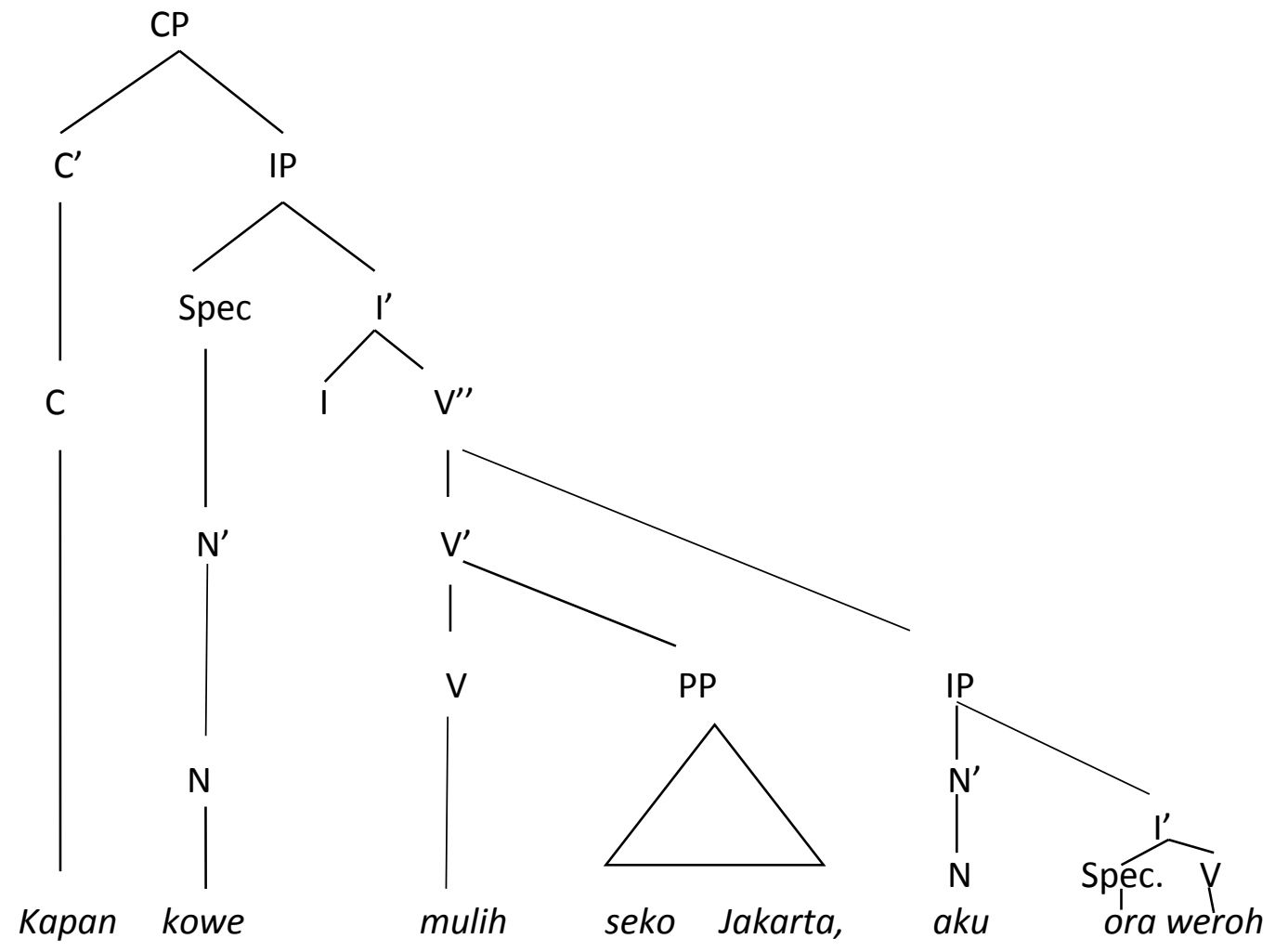


In the above data, the $\mathrm{N}^{\prime}$ kowe 'you' is located after $C$ when and forms NP which is a specifier of IP. PP merge with V' then immediately form VP because PP is an adverb of VP. VP is a complement of IP because it joins I and forms I'. C when is joined by $C^{\prime}$ and forms CP.

In the data above, it can be seen that the sentence structure with all the sentences is the same. It's just that the question word "when" changes its location to after NP "kowe". Whereas in that data, there is a slight difference. Where the NP "kowe" position moves to the beginning of the sentence and functions as a specifier.

The analysis in that figure above has specifier and complement functions. It is said to have a specifier function if the question word is placed in front of the sentence because the question word is joined by $C^{\prime}$ which will form a maximum projection of $\mathrm{CP}$. If the question word is placed at the end of the sentence, it has a complementary function because the question word joins directly with $\mathrm{V}$ and forms the first $\mathrm{V}$.

Thus, the question word in Javanese, they are apa (menapa) "what"; sapa (sinten) "who"; ing ngendi (wonten pundi) "where"; kepriye (kepripun, kadospundi) "how"; geneya (yagene, kena apa, kenging menapa) "why"; endi, pundi, ingkang pundi; ing ngendi "where"; menyang endi, dhateng pundi "to where"; saka ngendi, saking pundi "from where"; saka apa, saking menapa "from what"; saka sapa, saking sinten "from whom"; nganggo apa, ngangge menapa, ngagem menapa "with whom"; karo sapa, kaliyan sinten, kanggo sapa, kangge sinten, kagem sinten "with whom"; pira, pinten "how much"; kapan, dhek kapan, kala menapa, besuk kapan, benjang menapa "when"have the same function and the lexical function of the question word is a noun.

\subsection{Discussion}

It is found that interrogative sentences in Javanese can be formed from the specifier, complement, and description. Lexical categories that can occupy the position of the specifier are NP as in (12).

\begin{tabular}{cccc} 
(12) Opo tenan tuku & buku iki & nang pasar? \\
\hline Spec. & VP NP PP
\end{tabular}

'Is it true to buy the book at the market?'

$\begin{array}{cccc}\text { (13) Opo iso } & & \text { kowe } & \text { mbukak lawang iki? } \\ \text { Spec. } & \text { NP } & \text { VP } & \text { NP } \\ \text { 'Can } & \text { you open this door?' }\end{array}$

From the data analysis above the rules of the Javanese question sentences can be described as follows:

The total question sentences

$\left[\begin{array}{c}\mathrm{C} \\ \mathrm{QW}\end{array}\right]+\left[\begin{array}{l}\mathrm{SPES} \\ \mathrm{NP}\end{array}\right]+\left[\begin{array}{c}\mathrm{ADV} \\ \mathrm{NP} / \mathrm{PP}\end{array}\right]$

\section{Conclusions}

Based on the research conducted so far, it can be concluded that the question sentence in Javanese is a partial question sentence and a total question sentence. In the partial question sentence if the question word is placed at the beginning of the sentence it functions as a specifier. Conversely, if the question word is at the end of a sentence it functions as a 
complement. On the other hand, total question sentences in Javanese must be with the addition of a particle so that the question word has a complement function.

Further research on related topics are still open such as the structure of Javanese interrogative sentences in order to provide deeper analysis on the topic in the language.

\section{References}

Crystal, D. (2017). English as a Global Language. Cambridge: Cambridge University Press.

Fitriyani, D. Z. (2018). Interrgative Sentence in Minangkabau Language: X-bar Theory. Jurnal Retorika Ilmu Bahasa, 3 (1): 188-200.

Gapur, A., \&Pujiono, M. (2018). “Konstruksi Interogatif Polar Dalam Bahasa Jepang”. Ranah Jurnal Kajian Bahasa. Vol: 7 (1).

Hafrianto, J. \& Mulyadi. (2018). "Kalimat Tanya Dalam Bahasa Melayu Dialek Tamiang”. Litera Jurnal Penelitian Bahasa, Sastra, dan Pengajarannya, 17 (2): 186-201.

Haegemen, L. (1 992). tntroduction to Government and Binding Theory. Oxford: Btackwetl.

Harahap, R. (2018). Kata Tanya dalam Konstruksi InterogatifBahasa Mandailing. School Education Journal, 8(1): 56-65.

Mulyadi. (2010). Frasa Preposisi Bahasa Indonesia: Analisis X-Bar. Jurnal kajian sastra, 34 (1): 1-12.

Rodiyah, H. \& Mulyadi. (2018). "Kata Tanya Dalam Konstruksi Interogatif Bahasa Mandailing". School Education Journal. Vol: 8 (1).

Sudaryanto. (2015). Metode dan Aneka Teknik Analisis Bahasa Pengantar Penelitian Wacana Kebudayaan Secara Linguistis. Yogyakarta: Sanata Dharma University Press.

Sugiyono. (2006). Metode Penelitian Kuantitatif Kualitatif dan R\&D. Bandung: Alfabeta.

Sutopo, H. B. (2002). Metodologi Penelitian Kualitatif: Teori dan Aplikasinya Dalam Penelitian. Surakarta: sebelas maret university press.

Wini, T. (2009). "Kata Tanya Dalam Konstruksi Interogatif Bahasa Indonesia: Kajian Sintaksis dan Semantis". Sosiohumaniora Jurnal. Vol: 11 No. 1 - Maret 2009. Universitas Lampung. 